\title{
PSD93 Regulates Synaptic Stability at Neuronal Cholinergic Synapses
}

\author{
Michael J. Parker, ${ }^{1}$ Shengli Zhao, ${ }^{1}$ David S. Bredt, ${ }^{3}$ Joshua R. Sanes, ${ }^{4}$ and Guoping Feng ${ }^{1,2}$ \\ Departments of ${ }^{1}$ Neurobiology and ${ }^{2}$ Pathology, Duke University Medical Center, Durham, North Carolina 27710, ${ }^{3}$ Department of Physiology, University of \\ California at San Francisco, School of Medicine, San Francisco, California 94143, and ${ }^{4}$ Department of Anatomy and Neurobiology, Washington University \\ School of Medicine, St. Louis, Missouri 63110
}

Neuronal cholinergic synapses play important roles in both the PNS and CNS. However, the mechanisms that regulate the formation, maturation, and stability of neuronal cholinergic synapses are poorly understood. In this study, we use the readily accessible mouse superior cervical ganglion (SCG) and submandibular ganglion (SMG) to examine the assembly of the postsynaptic complex of neuronal cholinergic synapses. We find that novel splicing forms of PSD93 (postsynaptic density 93) are expressed in SCG. By immunostaining, we show that PSD93 proteins precisely colocalize with neuronal nicotinic acetylcholine receptors (nAChRs) at synapses of the SCG and SMG. Subcellular fractionation demonstrates that PSD93 is enriched in the PSD fraction of SCG, and coimmunoprecipitation shows that PSD93 and neuronal nAChRs form a complex in vivo. Furthermore, two additional components of the well characterized glutamatergic postsynaptic complex, GKAP/SAPAP (guanylate kinase domain-associated protein/synapse-associated protein-associated protein) and Shank/ ProSAP family proteins, are also present at neuronal cholinergic synapses. To assess the function of this protein complex at neuronal cholinergic synapses in vivo, we examined ganglia in mice that lack PSD93. We find that neuronal cholinergic synapses form properly in PSD93 null mice. After denervation, however, synaptic clusters of nAChRs disassemble much faster in mice lacking PSD93 than those in wild-type mice. These results demonstrate that PSD93 is a key component of the postsynaptic scaffold at neuronal cholinergic synapses and plays an important role in synaptic stability. In addition, these results suggest that the mechanism of postsynaptic scaffolding is conserved between neuronal cholinergic and glutamatergic synapses.

Key words: PSD93; PSD95; MAGUKs; cholinergic; nicotinic acetylcholine receptor; synapse; stability; denervation; superior cervical ganglion; submandibular ganglia

\section{Introduction}

The postsynaptic density (PSD), originally identified as electrondense material at the postsynaptic membrane, is the primary site of synaptic transmission of all chemical synapses (Kennedy, 2000). Biochemical and molecular studies of the PSD at glutamatergic synapses in the past few years have dramatically enhanced our understanding of its structure, function, and regulation. It is now clear that the PSD contains a supramolecular complex that includes $>80$ proteins (Husi et al., 2000; Walikonis et al., 2000; Yamauchi, 2002). One of the key components of the PSD at glutamatergic synapses is the PSD95 family of proteins, which includes PSD95/SAP90 (synapse-associated protein 90), PSD93/ chapsyn-110, SAP97, and SAP102 (Cho et al., 1992; Kistner et al.,

Received Aug. 19, 2003; revised 0ct. 7, 2003; accepted 0ct. 8, 2003.

This work was supported by a Sloan Fellowship from the Alfred P. Sloan Foundation, a Klingenstein Fellowship in the Neurosciences from the Esther and Joseph Klingenstein Fund Inc., a Scholar Research Program Award from the ELLB Foundation, Scientist Development Grant $0230064 \mathrm{~N}$ from the American Heart Association, National Institutes of Health Grants R01 NS42609 (G.F.) and NS036017 (D.S.B.), a postdoctoral fellowship from the Ruth K. Broad Foundation (M.J.P), and a McKnight Senior Scholar Award (J.R.S.). We thank Morgan Sheng for the GKAP antibody and Eckart Gundelfinger and Tobias Boeckers for Shank/ProSAP antibodies.

Correspondence should be addressed to Dr. Guoping Feng, Duke University Medical Center, Department of Neurobiology, 301D Bryan Research Building, Box 3209, Durham, NC 27710. E-mail: feng@neuro.duke.edu. DOI:10.1523/JNEUROSCI.3865-03.2004

Copyright $\odot 2004$ Society for Neuroscience $\quad$ 0270-6474/04/240378-11\$15.00/0
1993; Muller et al., 1995, 1996; Brenman et al., 1996; Kim et al., 1996).

Numerous studies have demonstrated that PSD95 family proteins function as scaffolds for the assembly of the large signaling complex at the postsynaptic membrane. PSD95 family proteins are MAGUKs (membrane-associated guanylate kinases) that contain multiple protein-protein interaction domains, including three PDZ (postsynaptic density 95/Discs large/zona occludens-1) domains, an Src homology 3 (SH3) domain, and an enzymatically inactive guanylate kinase-like (GK) domain. These domains interact with multiple signaling-adaptor proteins, such as neuronal nitric oxide synthase (nNOS) (Brenman et al., 1996), the Rho-GTPase interacting protein Citron (Zhang et al., 1999), and the synaptic Ras-GTPase activating protein SynGAP (Chen et al., 1998; Kim et al., 1998). Furthermore, the GK domain of MAGUKs interacts with GKAP/ SAPAP (guanylate kinase domain-associated protein/synapseassociated protein-associated protein) (Kim et al., 1997; Naisbitt et al., 1997; Satoh et al., 1997; Takeuchi et al., 1997), which, in turn, can form cytoskeleton links through interactions with Shank/ProSAP and Cortactin (Du et al., 1998; Boeckers et al., 1999a,b; Naisbitt et al., 1999).

Compared with glutamatergic synapses, the molecular composition and regulation of the postsynaptic complex at neuronal cholinergic synapses are not well understood. Studies from chick 
ciliary ganglion indicate that the large cytoplasmic loop of the $\alpha 3$ subunit of neuronal nicotinic acetylcholine receptors (nAChRs) is required for the postsynaptic targeting and/or anchoring of the receptor (Williams et al., 1998), suggesting that it may contain a nucleation site for postsynaptic scaffolding. In this report, we provide evidence that the postsynaptic complex at cholinergic synapses of mammalian autonomic ganglia resemble those at glutamatergic synapses. Specifically, in both the sympathetic superior cervical ganglion (SCG) and the parasympathetic submandibular ganglion (SMG), PSD93 proteins localize to neuronal cholinergic synapses and form a complex with neuronal nAChRs in vivo. In addition, the scaffolding proteins GKAP/SAPAP, which binds directly to PSD93, and Shank/ProSAP, which interacts with GKAP/SAPAP, are parts of this postsynaptic complex. Furthermore, analysis of mutant mice demonstrates a role for PSD93 in the stabilization of neuronal nAChRs at the postsynaptic membrane. While this manuscript was in preparation, a paper by Conroy et al. (2003) reported that neuronal MAGUKs are present at and regulate the function of cholinergic synapses in parasympathetic chick ciliary neurons. Together, these data suggest that PSD95 family-containing complexes may be a general feature of neuronal cholinergic synapses.

\section{Materials and Methods}

Animals. Mice with a targeted mutation of the PSD93 gene have been described previously (McGee et al., 2001). For denervation experiments, $P S D 93^{-/-}$mice were crossed with the GFP-J line of transgenic mice, which express green fluorescent protein specifically in neurons; these mice have been described previously (Feng et al., 2000). Mice were anesthetized with Ketamine-Xylazine by intraperitoneal injection, and preganglionic nerves innervating the submandibular ganglia were cut under a fluorescent dissecting microscope (model MZ LFIII; Leica, Wetzlar, Germany).

Antibodies. The mouse monoclonal antibody to the synaptic vesicle protein SV2 was obtained from the Developmental Studies Hybridoma Bank (University of Iowa, Iowa city, IA) (Buckley and Kelly, 1985). The mouse monoclonal anti-synaptophysin antibody was from Synaptic Systems (Göttingen, Germany). The rabbit polyclonal anti-synaptophysin was from Zymed Laboratories (South San Fransisco, CA). The mouse monoclonal anti-PDZ antibody was from Upstate Biotechnology (Lake Placid, NY). The rabbit polyclonal PSD93-specific antibody was from Chemicon (Temecula, CA). The rabbit polyclonal anti-GKAP antibody was a generous gift from Dr. Morgan Sheng (Massachusetts Institute of Technology, Cambridge, MA) (Kim et al., 1997). The rabbit polyclonal anti-ProSAP1 was a generous gift from Drs. Tobias Böckers (Westfaelische Wilhelms-University, Munster, Germany) and Ekart Gundelfinger (Leibniz Institute for Neurobiology, Magdeburg, Germany) (Boeckers et al., 1999a). The mouse monoclonal PSD95 antibodies were from Upstate Biotechnology and Transduction Laboratories (Lexington, KY). The rabbit polyclonal anti-SAP102 antibody was a generous gift from Dr. Michael Ehlers (Duke University, Durham, NC). The rabbit polyclonal anti-SAP97 antibody was from Affinity BioReagents (Golden, CO). The rat monoclonal MAB270 (anti- $\beta 2$ ) antibody was from the Developmental Studies Hybridoma Bank (Lindstrom, 1996). The rabbit polyclonal anti-AChR $\alpha 3$ antibody was generated and affinity purified in the laboratory using a fusion protein from a region of the large cytoplasmic loop that is unique to the $\alpha 3$ subunit. FITC-conjugated goat antimouse IgG $\mathrm{G}_{1}$ was from Roche Diagnostics (Indianapolis, IN). All other FITC- or Cy3-conjugated secondary antibodies were from Jackson ImmunoResearch (West Grove, PA).

Antibody characterization. COS-7 or QT6 cells were transfected with PSD938, PSD95-GFP, SAP97-GFP, or SAP102-myc. Expression of each neuronal MAGUK was verified by either GFP or myc-tag expression or by staining and blotting with the anti-PDZ antibody that recognizes all neuronal MAGUKs. To test antibody specificity, transfected COS-7 cells were fixed for immunostaining, and transfected QT6 cells were lysed for immunoblotting. Each antibody was then tested for their specificity by examining their cross-reactivity with other neuronal MAGUKs using transfected cells. For PSD95, we tested the following antibodies: mouse monoclonal anti-PSD95 from Affinity BioReagents (clone 6G6-1C9, catalog \#MA1-045; and clone 7E3-1B8, catalog \#MA1-046), Upstate Biotechnology (clone K28-86.2, catalog \#05-494), and Transduction Laboratories (clone 16, catalog \#610496), and rabbit polyclonal antiPSD95 from Chemicon (catalog \#1596). Only the mouse monoclonal anti-PSD95 from Upstate Biotechnology and Transduction Laboratories showed specificity. The rabbit polyclonal anti-PSD93 from Chemicon (catalog \#AB5168) and rabbit polyclonal anti-SAP97 antibody from Affinity BioReagents (catalog \#PA1-044) were specific. For SAP102, a guinea pig anti-SAP102 (Aoki et al., 2001) and a rabbit anti-SAP102 (Lau et al., 1996) were specific.

Cell culture. For transfection, COS-7 cells or quail fibroblast QT6 cells were plated in $35 \mathrm{~mm}$ tissue culture dishes with or without glass coverslips and cultured until 50\% confluent. Cells were transfected with $1 \mu \mathrm{g}$ of DNA of each construct per well using Lipofectamine 2000 (Invitrogen, Carlsbad, CA) and allowed to grow for $48 \mathrm{hr}$ after transfection. Cells were either lysed in $1 \times$ SDS loading buffer for SDS-PAGE and fixed for immunostaining or scraped into $2 \mathrm{ml}$ of PBS for coimmunoprecipitation studies.

Immunohistochemistry. Mice were deeply anesthetized, and submandibular and superior cervical ganglia from mutant or control mice were dissected and embedded in OCT compound (TissueTek, Torrance, CA), frozen in 2-methylbutane chilled in liquid nitrogen, and sectioned at 7 $\mu \mathrm{m}$ on a Leica CM 1850 cryostat.

For antibody staining, sections were rinsed with PBS for $5 \mathrm{~min}$, blocked with $2 \%$ BSA and 5\% normal goat serum in PBS for $1 \mathrm{hr}$, and incubated with primary antibody for $3 \mathrm{hr}$ to overnight. Sections stained with the anti-AChR $\beta 4$ antibody were treated with an antigen retrieval procedure. These sections were first fixed for $5 \mathrm{~min}$ in $4 \%$ paraformaldehyde (PFA) in PBS, rinsed in PBS, incubated with $0.1 \mathrm{~m}$ glycine in PBS for $10 \mathrm{~min}$, rinsed with PBS, and incubated for $1 \mathrm{hr}$ at $55^{\circ} \mathrm{C}$ in $0.1 \%$ SDS in PBS. Sections were then rinsed with PBS and blocked in 2\% BSA, 5\% normal goat serum, and $0.2 \%$ Triton X-100 (Sigma, St. Louis, MO) for 1 $\mathrm{hr}$. Primary antibody was added to the sections and incubated for $3 \mathrm{hr}$ to overnight. All sections were incubated with the proper secondary antibodies for 1-3 hr, washed with PBS, and mounted in $90 \%$ glycerol with $0.1 \%$ p-phenylenediamine.

PSD preparation. The PSD fractions of rat SCGs and mouse brains were prepared as described previously (Carlin et al., 1980; Cho et al., 1992; Ehlers, 2003). Briefly, mouse brain homogenates were centrifuged $(1000 \times g)$ to remove nuclei and tissue debris. The supernatant was centrifuged at 10,000 $\times g$ to yield a crude membrane (P2). The P2 pellet was washed and recentrifuged to obtain the washed crude synaptosomal pellet $\left(\mathrm{P} 2^{\prime}\right)$. The $\mathrm{P} 2^{\prime}$ fraction was subjected to hypo-osmotic shock and centrifuged at $25,000 \times g$ to yield the lysed synaptosomal membrane fraction (P3). Synaptic plasma membrane (SPM) fraction was obtained by sucrose gradient centrifugation of resuspended P3. To obtain the PSDII fraction, SPM was washed and pelleted twice with $0.5 \%$ Triton $\mathrm{X}-100$.

SCG lysate preparation and coimmunoprecipitation. SCGs were homogenized in a dounce homogenizer (100 strokes) with lysis buffer containing Complete protease inhibitor (Roche Diagnostics), 1\% Nonidet P-40 (Sigma), 0.5\% deoxycholate (Sigma), and 0.1\% SDS (Sigma). The lysate was incubated on ice for $1 \mathrm{hr}$ and then centrifuged at $18,000 \times \mathrm{g}$ for $30 \mathrm{~min}$. The supernatant was either diluted with $2 \times$ SDS-PAGE loading buffer for Western blot or used in coimmunoprecipitation as described below.

For coimmunoprecipitation, SCG lysates were incubated with $2 \mu \mathrm{g}$ of either polyclonal rabbit anti-AChR $\alpha 3$ antibody or rabbit anti-synapsin overnight with gentle mixing at $4^{\circ} \mathrm{C}$. Twenty-five microliters of protein G-agarose beads (1:1 slurry; Invitrogen) were then added and incubated for $2-4 \mathrm{hr}$ at $4^{\circ} \mathrm{C}$. Samples were centrifuged at $1000 \times g$ for $2 \mathrm{~min}$, and the supernatant was removed. Samples were washed six times for 5 min each with washing buffer (PBS with protease inhibitors and 1\% Triton X-100; Sigma). Proteins were eluted from agarose beads by addition of SDS loading buffer and boiling for $5 \mathrm{~min}$.

In situ hybridization. Mouse sequences encoding PSD93 $\alpha$ (nucleotide 1-319; GenBank accession number NM_022282), PSD93 $\delta$ (nucleotide 
1-420; GenBank accession number XM_133619), PSD93€ (nucleotide

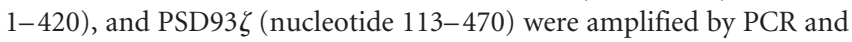
subcloned into pBluescript II SK+ vector (Stratagene, Palo Alto, CA). Plasmids were linearized with restriction enzymes that generated $5^{\prime}$ overhangs. Digoxigenin (DIG)-labeled RNA probes were synthesized with the MAXIscript in vitro RNA synthesis kit (Ambion, Austin, TX) using T3 and T7 RNA polymerases. DIG-labeled probes were quantified by dot blot and probed with alkaline phosphatase-conjugated anti-DIG antibody (Roche Diagnostics).

Adult ICR mice were killed with halothane in accordance with $\mathrm{Na}$ tional Institutes of Health and institutional protocols. SCGs were dissected, embedded in OCT compound (TissueTek), and frozen in 2-methylbutane chilled in liquid nitrogen. Twenty micrometer sections were cut on a cryostat and placed on Superfrost Plus slides (Fisher Scientific, Swanee, GA).

For hybridization, sections were fixed with 4\% PFA in PBS for $20 \mathrm{~min}$ at $4^{\circ} \mathrm{C}$ and washed three times for 3 min each with PBS. Sections were then acetylated for $10 \mathrm{~min}$ at room temperature in TEA buffer $(142 \mathrm{ml}$ of $\mathrm{dH}_{2} \mathrm{O}, 4.65 \mathrm{ml}$ of $5 \mathrm{M} \mathrm{NaCl}, 2.01 \mathrm{ml}$ of triethanolamine, $0.975 \mathrm{ml}$ of $8 \mathrm{M}$ $\mathrm{HCl}$; mix well and add $0.375 \mathrm{ml}$ of acetic anhydride just before use). After being washed three times with PBS, sections were incubated with hybridization buffer $(50 \%$ formamide, $5 \times$ SSC, $5 \times$ Denhardt's solution, 500 $\mu \mathrm{g} / \mathrm{ml}$ salmon sperm DNA, and $250 \mu \mathrm{g} / \mathrm{ml}$ yeast tRNA) for $2 \mathrm{hr}$ at room temperature and then with DIG-labeled RNA probes $(400 \mu \mathrm{g} / \mathrm{ml}$ in hybridization buffer, heated at $80^{\circ} \mathrm{C}$ for $10 \mathrm{~min}$, cooled on ice) overnight at $65^{\circ} \mathrm{C}$ in a chamber humidified with $50 \%$ formamide in $5 \times$ SSC.

After hybridization, sections were first rinsed two times for $5 \mathrm{~min}$ each with $5 \times$ SSC at room temperature, followed by four times for $1 \mathrm{hr}$ each with $0.2 \times \mathrm{SSC}$ at $65^{\circ} \mathrm{C}$. Sections were then cooled to room temperature and incubated with blocking buffer (10\% normal goat serum and $0.2 \%$ blocking reagent; Roche Diagnostics) for $1 \mathrm{hr}$, followed by incubation with alkaline phosphatase-conjugated anti-DIG antibody (1:2000; Roche Diagnostics) overnight at $4^{\circ} \mathrm{C}$. Sections were washed (four times for 10 min each) with TBS (150 mM NaCl and $10 \mathrm{~mm}$ Tris-HCl, pH 7.5) and incubated with color detection buffer ( $100 \mathrm{~mm} \mathrm{NaCl}, 50 \mathrm{mM} \mathrm{MgCl}_{2}, 0.24$ $\mathrm{mg} / \mathrm{ml}$ levamisole, and $100 \mathrm{~mm}$ Tris- $\mathrm{HCl}, \mathrm{pH}$ 9.5) for $5 \mathrm{~min}$. Color reactions were developed in the presence of nitro blue tetrazolium (NBT) $(0.35 \mathrm{mg} / \mathrm{ml})$ and 5-bromo-4-chloro-3-indolyl-phosphate (BCIP) $(0.175 \mathrm{mg} / \mathrm{ml})$ in color detection buffer. Color reactions were terminated by incubating sections in TE buffer ( $1 \mathrm{~mm}$ EDTA and $10 \mathrm{~mm}$ Tris- $\mathrm{HCl}$, pH 8.0).

SCG cDNA libraries: construction and screening. Mouse SCG cDNA libraries were constructed in $\lambda$ ZAPII phagemid vector with a cDNA library construction kit (Stratagene) following the instructions of the manufacturer. Briefly, double-stranded cDNAs were synthesized from mRNAs of mouse SCGs with either oligo-dT primers or random primers. Oligo-dT-primed cDNAs were unidirectionally cloned into EcoRI/XhoI sites of the $\lambda$ ZAPII phagemid vector. SCG CDNAs generated with random primers were nondirectionally cloned into the EcoRI site of the XZAPII phagemid vector. The oligo-dT-primed SCG cDNA library contains $9 \times 10^{6}$ primary recombinants with average insert size of $2.9 \mathrm{~kb}$. The random-primed SCG cDNA library contains $1.5 \times$ $10^{7}$ primary recombinants with average insert size of $1.8 \mathrm{~kb}$. Both libraries have $<1 \%$ background (phages without inserts).

For anti-PDZ antibody screening, the oligo-dT-primed SCG cDNA library was plated at a density of $5 \times 10^{4}$ plaques per $15 \mathrm{~cm}$ plate and screened with the picoBlue Immunoscreening Kit (Stratagene). Briefly, proteins from phagemid clones were induced and transferred to Protran nitrocellulose filter membranes (Schleicher \& Schuell, Dassel, Germany) by placing isopropylthio- $\beta$-galactoside-soaked membrane on phagemid plates. Membranes were then blocked for $1-2 \mathrm{hr}$ with blocking buffer (5\% BSA and 10\% normal goat serum in PBS), incubated with mouse monoclonal anti-PDZ antibody overnight, washed six times with washing buffer (TBS plus $0.3 \%$ Tween 20), and reincubated with alkaline phosphatase-conjugated goat anti-mouse secondary antibody for 2-4 hr, followed by six washes with washing buffer. The membranes were then incubated with color detection buffer $\left(100 \mathrm{mM} \mathrm{NaCl}, 50 \mathrm{mM} \mathrm{MgCl}_{2}\right.$, and $100 \mathrm{~mm}$ Tris-HCl, $\mathrm{pH}$ 9.5) for $5 \mathrm{~min}$. Color reactions were developed in the presence of NBT $(0.35 \mathrm{mg} / \mathrm{ml})$ and BCIP $(0.175 \mathrm{mg} / \mathrm{ml})$ in color detection buffer. Color reactions were terminated by incubating membranes in TE buffer. A total of $2 \times 10^{6}$ clones were screened with the anti-PDZ antibody, and 85 positive clones were recovered.

For library screening with PSD93 cDNA probes, mouse sequence encoding PSD93 $\alpha$ (nucleotide 181-1243; GenBank accession number NM_011807) was amplified by PCR and subcloned into pBluescript II SK+ vector (Stratagene). DNA was labeled with DIG using the Dig High Prime DNA Labeling and Detection kit (Roche Diagnostics). Randomprimed cDNA library was plated at a density of $1 \times 10^{5}$ plaques per $15 \mathrm{~cm}$ plate. Phage DNAs were transferred to nylon membranes, denatured by autoclaving for $3 \mathrm{~min}$, and cross-linked to the membrane by UV crosslinking. Membranes were washed twice with $2 \times$ SSC, prehybridized for 2 hr at $45^{\circ} \mathrm{C}$ in Easy-Hyb solution (Roche Diagnostics), and then incubated with DIG-labeled cDNA probes $(50-100 \mathrm{ng} / \mathrm{ml}$ in Easy-Hyb solution) overnight at $45^{\circ} \mathrm{C}$. After hybridization, membranes were washed twice (10 min each) with $2 \times$ SSC and $0.1 \%$ SDS at room temperature, followed by washing twice $\left(30 \mathrm{~min}\right.$ each) with $0.2 \times$ SSC and $0.1 \%$ SDS at $65^{\circ} \mathrm{C}$. Membranes were rinsed three times with TBS, blocked with $1 \times$ blocking solution (Roche Diagnostics) for $2 \mathrm{hr}$ and then incubated with anti-DIG antibody (1:5000 in $1 \times$ blocking solution) for $4 \mathrm{hr}$, followed by washing six times with TBS plus $0.3 \%$ Tween 20 . Color reactions were developed in the presence of NBT and BCIP as described above. A total of $1 \times 10^{6}$ clones were screened, resulting in the identification of 45 positive clones.

Reverse transcription-PCR. Poly $\left(\mathrm{A}^{+}\right)$RNA from mouse SCGs and brains were prepared as described previously (Feng et al., 1998a). cDNA was synthesized with Superscript reverse transcriptase (Stratagene) using oligo-dT as a primer. PCR primers were designed to specifically amplify $\sim 1000$ nucleotide fragments of various splicing forms of PSD93 and a $1.5 \mathrm{~kb}$ fragment of EF- $1 \alpha$ (elongation factor- $1 \alpha$ ) as a control (Gruber and Levine, 1997). The following primers were used: PSD $93 \alpha$ F (CTGAGCTCTCACCACTCAGTGCCTTC) and PSD93R (CGGTGGCCCATAAGGATCAGT); PSD93 $\beta$ F (AGCTGCCGCTCGGTCTAGGCTG) and PSD93R; PSD93 $\gamma$ F (GTGAAGAAGCTATGCAACATGCGT) and PSD $93 \gamma$ R (CGAGTTGCAGTACTGTGCTGG); PSD938F(GGGAGGAAGCCTTTCTATGCAG) and PSD93R; PSD93єF (GCCAACTGGATGTGTGTGAGCCG) and PSD93R; PSD93 $\zeta$ F (CGAGCTTTGTCATTACTGGAGG) and PSD93 $\zeta \mathrm{R}$ (CCATCTTTCTGTGCAGCTCCACC); and EF- $1 \alpha$ F (GTGAAAACCACCGCTAATTCAAAGC) and EF- $1 \alpha \mathrm{R}$ (CCACAACATTCTTTCCTTCTGAAGG). Semiquantitative PCR was performed by a modification of the method of Freeman et al. (1994). Briefly, EF- $1 \alpha$ RNA was used to calibrate the relative amount of RNA in SCG and brain samples, and cycle number was adjusted to be within the linear range of amplification. Once optimal conditions were determined, PCR was performed to compare the relative abundance in the SCG and brain of each alternatively spliced form.

\section{Results}

\section{PSD93 colocalizes with neuronal nAChRs at mammalian cholinergic synapses}

To analyze the molecular mechanisms that regulate the formation, stability, and plasticity of neuronal cholinergic synapses, we chose two autonomic ganglia in the mouse: the sympathetic SCG and the parasympathetic SMG. This system has several advantages. First, the majority of synapses in both ganglia are cholinergic. This relative homogeneity simplifies the correlation of structural, functional, and molecular information and provides a pure population of synapses for biochemical and molecular studies. Second, synapses within SCG and SMG are accessible and amenable to experimental manipulations in vivo (Kawa and Roper, 1984; Feng et al., 1998a). Third, using mouse ganglia permits molecular genetic approaches (Feng et al., 1998a).

We showed previously that neither rapsyn, the primary scaffolding protein of the cholinergic neuromuscular junction, nor gephyrin, the primary scaffolding protein of glycinergic and GABAergic synapses, is present at neuronal cholinergic synapses in the SCG (Feng et al., 1998a). We began the present study by asking whether MAGUKs are present at these synapses. To this 


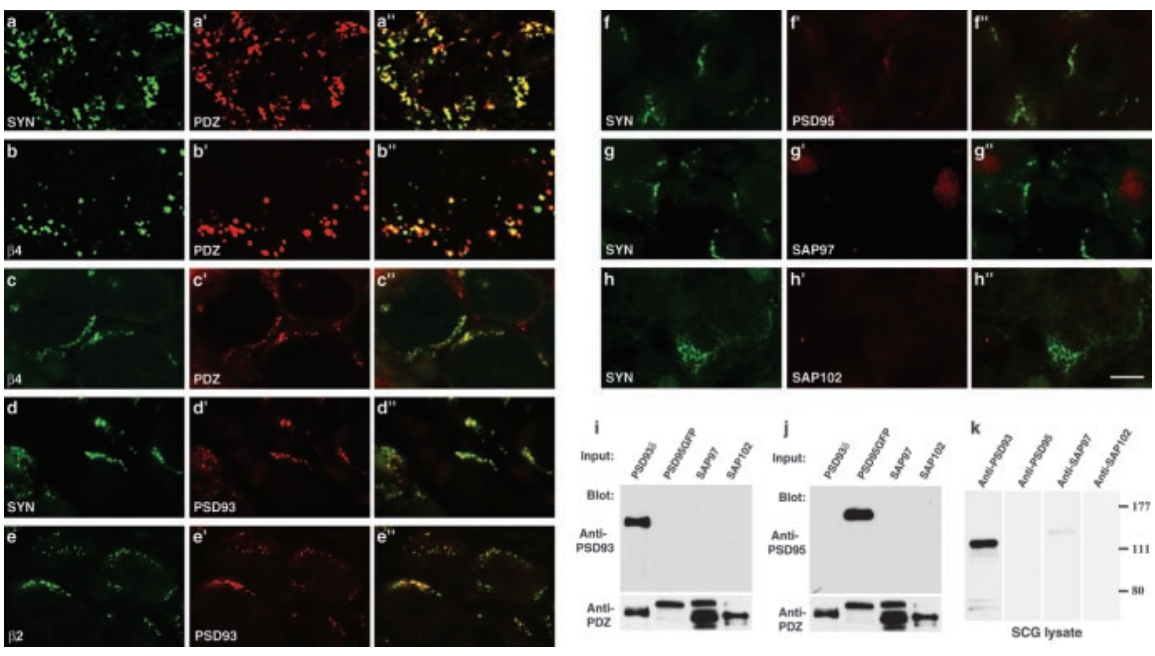

Figure 1. PSD93 is expressed at neuronal cholinergic synapses. $a-c$, Sections of mouse SCG $(a, b)$ or SMG $(c)$ were double stained with the anti-PDZ antibody plus antibodies to synaptophysin (SYN; $\left.a, a^{\prime}\right)$ or the nAChR $\beta 4$ subunit $\left(b, b^{\prime}, c, c^{\prime}\right)$. Staining of the anti-PDZ antibody colocalizes with synaptophysin $\left(a^{\prime \prime}\right)$ and the nAChR $\beta 4$ subunit $\left(b^{\prime \prime}, c^{\prime \prime}\right) . d, e$, PSD93 is concentrated at synapses $\left(d-d^{\prime \prime}\right)$ and colocalizes with nAChRs $\left(e-e^{\prime \prime}\right)$ in mouse SMG. $f-h$, Sections of mouse SMG were double stained with anti-synaptophysin $(f-h)$ and antibodies against PSD95 $\left(f^{\prime}\right)$, SAP97 $\left(g^{\prime}\right)$, or SAP102 $\left(h^{\prime}\right)$. Low level of PSD95 expression was detected at SMG synapses. No synaptic localization of SAP97 or SAP102 was detected. $i, j$, Mammalian expression vectors of PSD93 $\delta$, PSD95-GFP, SAP97, and SAP102 were transfected into quail QT6 fibroblast cells, and lysates were subjected to Western blot analysis. The anti-PSD93 ( $i$ ) and anti-PSD95 ( $j$ ) antibodies show excellent specificity. The blot was stripped and reprobed with the anti-PDZ antibody to verify the expression of various constructs (bottom panels of $i, j$ ). $k$, Rat SCG lysates were probed with antibodies specific to PSD93, PSD95, SAP97, and SAP102. Only PSD93 is highly expressed in SCG. Scale bar, $5 \mu \mathrm{m}$.

nAChRs (Fig. 1e). We also observed weak synaptic staining of PSD95 in SMG (Fig. $1 f)$, but its levels were much lower than those of PSD93, although both antibodies stained transfected cells to a similar extent (data not shown). No synaptic staining of SAP97 or SAP102 was detected (Fig. $1 g, h$ ). Similar results were also obtained from SCG preparations (data not shown). Consistent with the immunostaining results, Western blot analysis of SCG lysate showed abundant expression of PSD93 but not PSD95, SAP97, or SAP102 (Fig. $1 k)$. Thus, PSD93 is the predominant MAGUK expressed at neuronal cholinergic synapses of mouse autonomic ganglia.

\section{Characterization of PSD93 splicing} forms at neuronal cholinergic synapses Neuronal MAGUKs show considerable alternative splicing in brain (Lue et al., 1994; Muller et al., 1995, 1996; Brenman et al., 1996; Chetkovich et al., 2002; Rumbaugh et al., 2003). Specifically, alternative splicing at the $\mathrm{N}$ termini regulates synaptic trafficking and targeting of PSD95 and PSD93 (Firestein et al., 2000; Chetkovich et al.,

end, we first stained SCG sections with a monoclonal antibody (anti-PDZ) that recognizes the conserved PDZ domains of all four neuronal MAGUKs. To mark synapses, sections were costained with an antibody to the synaptic vesicle protein, synaptophysin. SCG neurons have short dendrites (Purves and Lichtman, 1985), and synapses in SCG are concentrated in neuropilrich regions between neurons and appear as punctate patches (Feng et al., 1998a). As shown in Figure 1a, the anti-PDZ antibody strongly stains SCG synapses. We found previously that neuronal nAChRs cluster at synapses in mouse SCG (Feng et al., 1998a). Double immunostaining shows that most PDZ-rich puncta colocalize with the $\beta 4$ subunit (Fig. $1 b$ ).

In contrast to synapses in the SCG, those of the SMG are axo-somatic (Lichtman, 1977). The large size of these synapses and their localization on cell bodies make them easier to identify and visualize (Purves and Hadley, 1985; Snider, 1987; Gan et al., 2003). To test whether MAGUKs also localize at SMG synapses, we double stained SMG sections with the anti-PDZ antibody and either the anti- $\beta 4$ antibody (Fig. $1 c$ ) or the anti- $\beta 2$ antibody (data not shown). As in SCG, neuronal nAChRs are clustered at synapses on neuronal cell bodies, as indicated by their colocalization with the presynaptic vesicle proteins synaptophysin and SV2 (data not shown). Similarly, patterns of anti-PDZ antibody staining and anti- $\beta 4$ staining match precisely (Fig. $1 c$ ). Thus, in both sympathetic and parasympathic ganglia, MAGUKs are present at neuronal cholinergic synapses.

To determine which MAGUKs are present at neuronal cholinergic synapses, we stained SMG sections with antibodies specific for PSD95/SAP90, PSD93/chapsyn-110, SAP97, and SAP102 (Fig. $1 d-h$ ). When tested in transfected COS7 cells, all four antibodies stained their respective proteins strongly and specifically (Fig. $1 i, j$ and data not shown) (for details of antibody characterization, see Materials and Methods). In SMG, PSD93 is highly expressed and localized to the synapse, as evidenced by its precise colocalization with synaptophysin (Fig. $1 d$ ) and the $\beta 2$ subunit of
2002). We therefore examined alternative splicing of the PSD93 gene in autonomic ganglia. To facilitate the identification of unique forms at neuronal cholinergic synapses, we constructed a mouse SCG cDNA library and screened it with both the anti-PDZ antibody and a PSD93-specific cDNA probe. The screen with the anti-PDZ antibody also tested whether synaptic staining by the anti-PDZ antibody may represent a novel MAGUK. Among the 85 positive clones isolated by screening with the anti-PDZ antibody, 74 encoded PSD93, five encoded PSD95, and one encoded SAP102; no novel homologues were identified. The relative abundance of PSD93 clones in the SCG cDNA library is consistent with our immunostaining results showing that PSD93 is the predominant MAGUK at neuronal cholinergic synapses.

Sequence analysis of PSD93 clones from both the antibody and cDNA probe screens revealed three novel splicing forms of PSD93. Previous studies of rat brain identified three alternative splicing forms of PSD93 (PSD93 $\alpha$, PSD93 $\beta$, and PSD93 $\gamma$, corresponding to PSD93-5'b, PSD93-5' a, and PSD93-5' c according to Brenman et al., 1996), with the most abundant being PSD93 $\alpha$ (Brenman et al., 1996). Surprisingly, the previously identified brain splicing forms were not isolated from the SCG library, with the exception of one clone encoding the PSD93 $\beta$ isoform. Of the three new isoforms (PSD93 $\delta$, PSD93 $\epsilon$, and PSD93 $\zeta$ ) that we identified, PSD $93 \delta$ is most abundant. Both PSD93 $\delta$ and PSD93 $\epsilon$ diverge from PSD93 $\alpha$ (the most abundant brain isoform) upstream of alanine 69, whereas PSD93 $\zeta$ diverges from PSD93 $\alpha$ upstream of lysine 15 (Fig. 2a). Compared with PSD93 $\alpha$, the $\mathrm{N}$ termini of $\mathrm{PSD} 93 \delta$ and PSD93 $\zeta$ are 35 and 124 amino acids longer, respectively, and PSD93 $\epsilon$ is 42 amino acids shorter. The PSD93 $\delta$ isoform contains two pairs of $\mathrm{N}$-terminal cysteines for potential palmitoylation, a modification that has been shown to mediate synaptic targeting of PSD95 (Topinka and Bredt, 1998; Craven et al., 1999). Interestingly, the PSD93 $\zeta$ isoform does not have the cysteine pairs. Rather, it contains an L27 domain, which 
has been shown to mediate synaptic targeting of the PSD95 $\beta$ isoform through protein-protein interactions (Chetkovich et al., 2002). Neither a cysteine pair nor an L27 domain is present in the PSD93 $\epsilon$ (Fig. $2 a$ ). These data suggest that ganglionic neurons may use alternative splicing to regulate the synaptic targeting of PSD93.

To verify our observations from the SCG library screening, we first used reverse transcription (RT)-PCR to estimate the relative abundance of the splicing variants in the SCG and the brain. The transcripts of PSD $93 \alpha$, PSD93 $\beta$, and PSD93 $\gamma$ isoforms are readily detected from mouse brain by RT-PCR but are not detected from the SCG using the same conditions. In contrast, the three new isoforms, $\operatorname{PSD} 93 \delta$, PSD93 $\epsilon$, and PSD93 $\zeta$, are detected in both the brain and SCG (Fig. 2b). The transcript for PSD93 $\delta$ is equally abundant in the brain and the SCG, whereas transcripts for PSD93 $\epsilon$ and $\mathrm{PSD} 93 \zeta$ are more abundant in the brain than in the SCG (Fig. 2b).

We next examined the expression of the various isoforms in SCG by in situ hybridization. We made probes specific for the PSD93 $\alpha$, PSD93 $\delta$, PSD93 $\epsilon$, and PSD93 $\zeta$ isoforms. Little signal was detected in the SCG with the probe for PSD93 $\alpha$ (Fig. $2 c$ ), although strong signals were detected in the brain with the same probe (data not shown). This is consistent with our results from the library screening and RT-PCR, indicating that PSD93 $\alpha$, although abundant in the brain, is expressed at low levels if at all in the SCG. In contrast, $\operatorname{PSD} 93 \delta$, PSD93 $\epsilon$, and PSD93 $\zeta$ were all expressed in SCG neurons, with the PSD93 $\delta$ probe giving the strongest signal (Fig. 2c). Together, these data strongly suggest that ganglionic neurons express unique splicing forms of PSD93.

To characterize PSD93 splicing forms at the protein level, we expressed various splicing forms of PSD93 in quail QT6 fibroblast cells. The size differences of the major brain and SCG splicing forms make it possible to distinguish them on Western blots (Fig. 2d), thus allowing us to predict the isoforms expressed in SCG on the basis of their apparent molecular weights. A single major band at $\sim 120 \mathrm{kDa}$ was detected in SCG lysate when probed with a PSD93-specific antibody that is able to recognize all $\mathrm{N}$-terminal splicing forms. This band comigrates with the PSD93 $\delta$ isoform transfected in QT6 cells (Fig. 2d). Although conclusive evidence will require the generation of isoform-specific antibodies, these data suggest that PSD93 $\delta$ is the predominant PSD93 splicing form expressed at ganglionic cholinergic synapses.

\section{PSD93 is enriched in PSD and forms a complex with neuronal} nAChRs in vivo

MAGUKs are core components of the PSD at glutamatergic synapses (Kennedy, 2000). To test whether PSD93 is also a compo- nent of the PSD at neuronal cholinergic synapses, we prepared PSD fractions from rat SCG and probed them with PSD93specific antibodies. As shown in Figure 3a, PSD93 is highly enriched in the PSD fraction prepared from rat SCG. In contrast, PSD95 was not detected in either SCG lysate or SCG PSD fractions (Fig. 3b).

MAGUKs form a complex with glutamate receptors through either a direct interaction (with NMDA receptors) or an indirect interaction (with AMPA receptors via Stargazin), and these interactions have been implicated in regulating the synaptic targeting and anchoring of glutamate receptors at the postsynaptic membrane (Sheng and Sala, 2001; McGee and Bredt, 2003). To determine whether PSD93 forms a complex with neuronal nAChRs, we performed coimmunoprecipitation from the SCG with a polyclonal antibody against the $\alpha 3$ subunit of the nAChR and probed the imunoprecipitates with the monoclonal anti- 
a

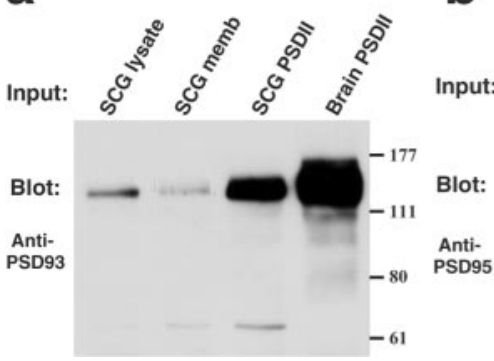

b

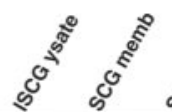

C

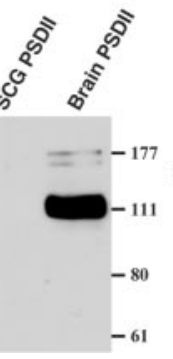

IP:

Figure 3. PSD93 is enriched in the PSD and forms a complex with neuronal $\mathrm{nAChRs}$ in vivo. a, Five micrograms of rat SCG lysate, crude membrane (memb), twice Triton X-100-washed PSD preparations (PSDII), and mouse brain PSDII were subjected to Western blot analysis with the anti-PSD93 antibody. PSD93 is highly enriched in the PSDII fraction of SCG. $b$, The same blot in $a$ was stripped and reprobed with an anti-PSD95 antibody. C, SCG lysate was immunoprecipitated with either the rabbit anti-nAChR $\alpha 3$ antibody or an anti-synapsin antibody and probed with the monoclonal anti-PDZ antibody that recognizes PSD93 in SCG.
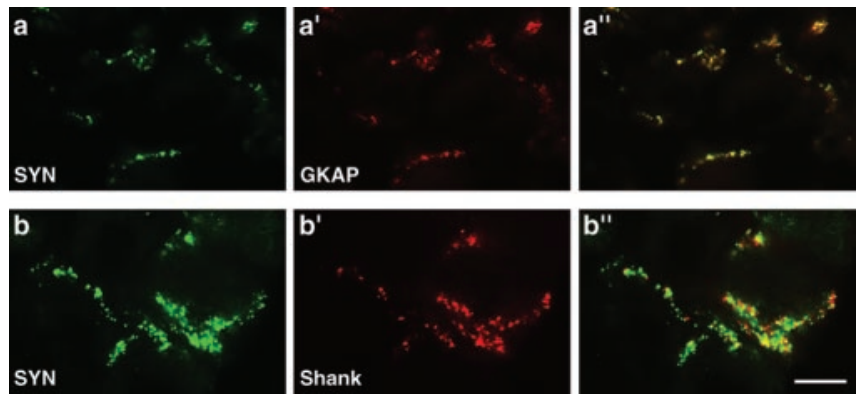

Figure 4. GKAP/SAPAP and Shank/ProSAP proteins are also clustered at neuronal cholinergic synapses. Sections of mouse SMG were double stained with anti-synaptophysin (SYN; $a, b)$ plus antibodies against GKAP $\left(a^{\prime}\right)$ or Shank $\left(b^{\prime}\right)$. Both GKAP and Shank are localized at synapses of mouse SMG $\left(a^{\prime \prime}, b^{\prime \prime}\right)$. Scale bar, $5 \mu \mathrm{m}$.

PDZ antibody. As shown in Figure $3 c$, antibodies to nAChRs specifically coprecipitated a protein recognized by the anti-PDZ antibody and that comigrates with PSD93. Together with the fact that PSD93 is the only neuronal MAGUK detected in the SCG PSD fractions, these data suggest that PSD93 forms a complex with neuronal nAChRs in vivo.

\section{The postsynaptic complex at neuronal cholinergic synapses contains multiple scaffolding proteins}

The supramolecular complex at the postsynaptic membrane contains multiple scaffolding proteins (Garner et al., 2000; Kennedy, 2000; Sheng and Sala, 2001; McGee and Bredt, 2003). In addition to interacting with NMDA receptors and nNOS, MAGUKs also interact with the GKAP/SAPAP family of proteins. GKAP/SAPAP proteins further interact with a variety of proteins, including Shank/ProSAP, another class of multidomain scaffolding proteins (Boeckers et al., 1999a,b; Naisbitt et al., 1999; Sheng and Kim, 2000). Shank/ProSAP proteins, in turn, bind to the actinbinding protein Cortactin, potentially linking the complex to the cytoskeleton. Furthermore, Shank/ProSAP proteins also bind to Homer, a metabotropic glutamate receptor binding protein (Sheng and Kim, 2000). These interactions increase the complexity and regulatory capability of the postsynaptic complex (Kennedy, 2000).

To test whether a similar core group of scaffolding proteins is present at neuronal cholinergic synapses, we examined the expression of GKAP/SAPAP and Shank/ProSAP using specific antibodies. The anti-GKAP antibody recognizes all four members of the family (Kim et al., 1997) (J. M. Welch, D. Wang, and G.
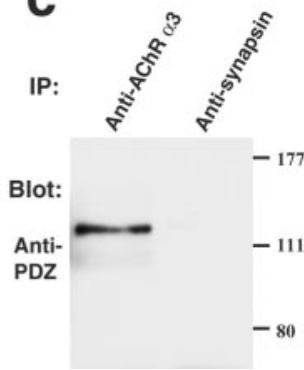

Feng, unpublished results). The antiShank antibody is specific for Shank1/ProSAP2 (Boeckers et al., 1999a). We found that both GKAP/SAPAP and Shank/ProSAP are expressed in the SMG and are highly concentrated at synapses (Fig. $4 a, b)$. The precise synaptic localization of GKAP/SAPAP and Shank/ProSAP and their ability to interact with the actin cytoskeleton provide a possible mechanism whereby nAChRs might be tethered to the cytoskeleton, thus stabilizing the receptors at the synapse.

\section{Formation and stability of neuronal cholinergic synapses in the absence of PSD93}

To determine the function of PSD93 at neuronal cholinergic synapses, we examined synapses in the SMG of PSD93-deficient mice. PSD93 knock-out mice are viable, fertile, and outwardly normal (McGee et al., 2001), suggesting that the basic function of the autonomic nervous system is intact. No PSD93 proteins were detected in the SMG of the knock-out mice (Fig. 5a). To determine whether neuronal nAChRs are anchored at synapses in the absence of PSD93, we stained SMG sections for the presynaptic vesicle protein synaptophysin and the $\beta 2$ and $\beta 4$ subunits of the nAChRs. We found that neuronal nAChRs are clustered at synapses in the SMG of PSD93 mutant mice and that receptor clusters are qualitatively indistinguishable from those of wild-type SMG (Fig. $5 c, d$ ), indicating that PSD93 is dispensable for clustering of neuronal nAChRs at ganglionic synapses. Staining with the anti-PDZ antibody showed a low level of residual staining, comparable with the PSD95 staining seen in the wildtype SMG (Fig. 5b). Moreover, staining for individual members of MAGUKs did not reveal any detectable upregulation (data not shown). Although we cannot exclude the possibility that other MAGUKs may play a role at this synapse, our data do not show compensation for the loss of PSD93 by other MAGUKs.

We next examined the localization of other scaffolding proteins in the absence of PSD93. In the PSD93 knock-out mice, the synaptic localization of both GKAP/SAPAP and Shank/ProSAP documented above for wild-type mice (Fig. 4) is maintained (Fig. $5 e, f)$, indicating that interactions with PSD93 are not critical for the synaptic localization of either protein.

Although PSD93 is not essential for clustering nAChRs, it might play a role in stabilizing receptor clusters. Denervation of SMG allows study of the stability of neuron-neuron synapses in vivo. It eliminates synaptic adhesion and presynaptic factors that promote receptor clustering, leading to the disassembly of the postsynaptic complex at a rate inversely proportional to its structural integrity.

We found previously that, in the SCG of wild-type mice, presynaptic nerve terminals degenerate $3 \mathrm{~d}$ after denervation, whereas neuronal nAChR clusters persist (Feng et al., 1998a). In this study, we used the SMG because the axo-somatic synapses are much easier to visualize and quantify. We first mated PSD93 knock-out mice to a line of Thyl-GFP mice in which the preganglionic axons and terminals, but not postganglionic neurons, are specifically labeled with GFP (Feng et al., 2000). This enabled us to transect the preganglionic axon bundles innervating the SMG under a fluorescent dissecting microscope with minimal perturbation and tissue damage (Fig. 6a,b). Denervations were performed unilaterally, and both denervated and contralateral non- 

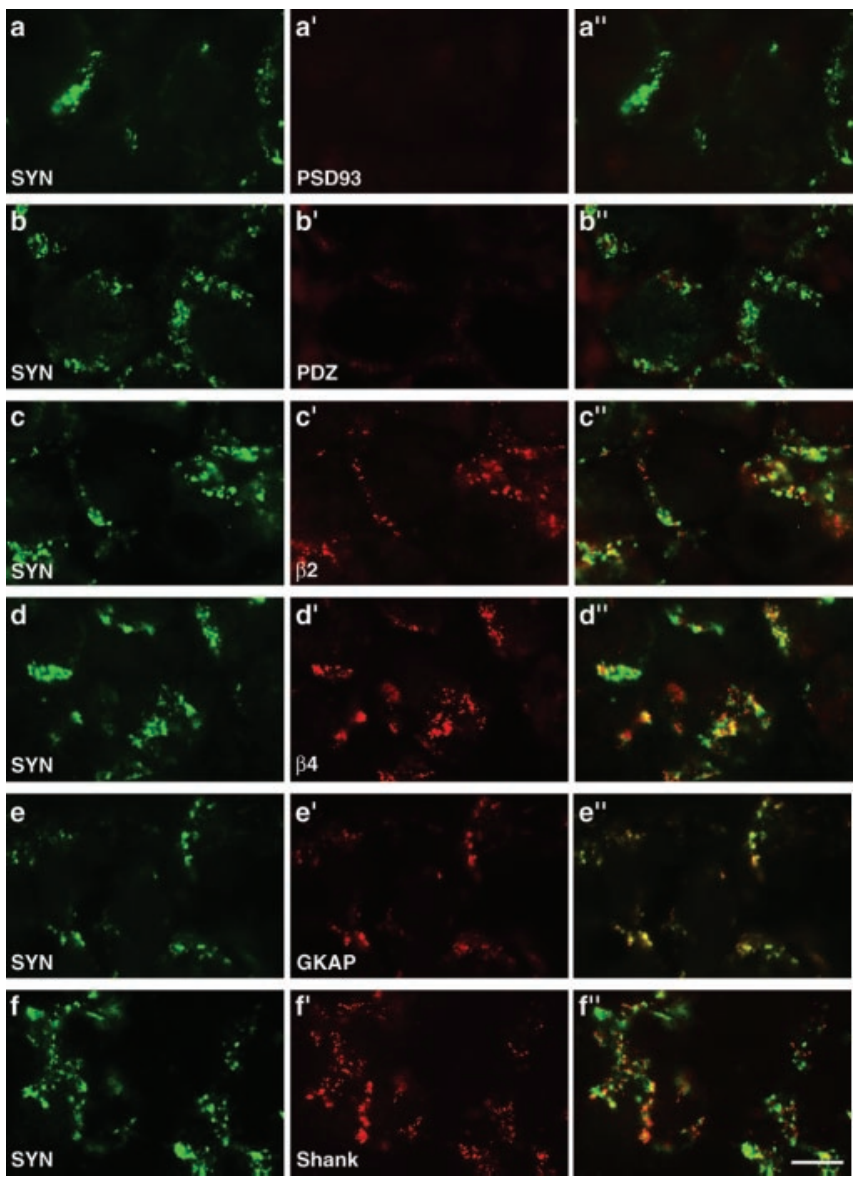

Figure 5. Synaptic clusters of neuronal nAChRs, GKAP, and Shank form in the SMG of $\mathrm{PSD}^{-1-}$ mice. Sections of SMG from PSD93 ${ }^{-1-}$ mice were double stained with antisynaptophysin (SYN; $a-f$ ) plus antibodies against PSD93 $\left(a^{\prime}\right)$, anti-PDZ $\left(b^{\prime}\right)$, nAChR $\beta 2\left(c^{\prime}\right)$, nAChR $\beta 4\left(d^{\prime}\right), \operatorname{GKAP}\left(e^{\prime}\right)$, and Shank $\left(f^{\prime}\right)$. PSD93 staining is completely absent in the SMG of PSD93 ${ }^{-1-}$ mice $\left(a^{\prime}\right)$, and anti-PDZ staining is present at low level $\left(b^{\prime}\right)$. However, $\mathrm{nAChR} \beta 2$ subunit, $\beta 4$ subunit, GKAP, and Shank are all clustered at synapses of SMG from PSD93 mutant mice $\left(c^{\prime}-f^{\prime}, c^{\prime \prime}-f^{\prime}\right)$. Scale bar, $5 \mu \mathrm{m}$.

denervated (as controls) SMG were dissected 2, 4, and $7 \mathrm{~d}$ postoperatively. Full denervation of the SMG was verified at each time point by immunostaining SMG sections for the presynaptic protein synaptophysin. Receptor clusters were assessed by immunostaining for the $\beta 2$ subunit of nAChRs using the MAB270 monoclonal antibody (Whiting et al., 1987; Feng et al., 1998a). Because each neuron in the SMG is easily visualized in these sections, we quantified receptor clusters by counting the number of neurons that had receptor clusters as a percentage of the total neurons on the section.

In both wild-type and PSD93 knock-out mice, presynaptic terminals degenerated to near completion $2 \mathrm{~d}$ after denervation, as indicated by the lack of synaptophysin staining (Fig. $6 c, d$ ). In wild-type SMG, the majority of neurons maintain nAChR clusters after denervation for 2 and $4 \mathrm{~d}$ ( 85 and 67\%, respectively). By day 7 after denervation, the fraction of neurons with receptor clusters was reduced to $24 \%$ (Fig. 6c). In contrast, in the

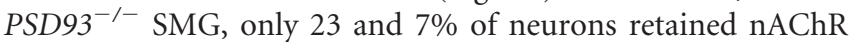
clusters after denervation for 2 and 4 d, respectively (Fig. $6 d$ ). Thus, postsynaptic receptor clusters at neuronal cholinergic synapses of $P S D 93^{-/-}$mice disassemble at an approximately threefold to fourfold accelerated rate when denervated (Fig. 6e).

To test whether deletion of PSD93 also accelerates the disas- sembly of other postsynaptic proteins, we compared synaptic localization of GKAP/SAPAP and Shank/ProSAP in denervated SMG of wild-type and PSD93 knock-out mice. Unlike nAChRs, synaptic clusters of both GKAP/SAPAP and Shank/ProSAP in wild-type SMG persisted for $7 \mathrm{~d}$ after denervation (Fig. 7a,c). Furthermore, the quality and quantity of clusters of these two proteins in PSD93 ${ }^{-1-}$ SMG were indistinguishable from those of wild-type SMG (Fig. $7 b, d$ ). These data indicate that the synaptic localization of GKAP/SAPAP and Shank/ProSAP proteins does not depend on their interactions with PSD93.

\section{Discussion}

Neuronal cholinergic synapses play important roles in both the PNS and CNS (Dani and Heinemann, 1996; Role and Berg, 1996). Alterations in $\mathrm{nAChR}$ function and expression have been implicated in several neurological disorders, including Alzheimer's disease, epilepsy, and schizophrenia (Lena and Changeux, 1997; Lindstrom, 1997; Perry et al., 1999). However, the molecular mechanisms regulating the assembly and maintenance of the postsynaptic complex at neuronal cholinergic synapses are still poorly understood. In this report, we provide evidence that PSD93, GKAP/SAPAP, and Shank/ProSAP are all present at the postsynaptic membrane of autonomic neuronal cholinergic synapses. This core complex plays a key role in regulating the stability of neuronal cholinergic synapses, likely by interacting with the actin cytoskeleton. Furthermore, by providing docking sites for various signaling molecules, this core scaffold also provides a link from receptor activation to downstream signaling events.

It has been well established that the multidomain proteins of MAGUKs, GKAP/SAPAP family, and Shank/ProSAP family are key scaffolding molecules at the glutamatergic synapses (Garner et al., 2000; Kennedy, 2000; Sheng and Sala, 2001; McGee and Bredt, 2003). Our studies demonstrate that these key scaffolding proteins are also important components of neuronal cholinergic synapses. A recent study has shown that MAGUKs are also present in chick ciliary ganglion neurons and regulate the function of neuronal cholinergic synapses (Conroy et al., 2003). MAGUKs (Rafael et al., 1998) and GKAP/SAPAP proteins (Welch, Wang, and Feng, unpublished results) have also been found at the neuromuscular junction. These data raise the intriguing possibility that all excitatory synapses use the same group of core scaffolding proteins. On the contrary, none of these scaffolding proteins have been found at GABAergic or glycinergic synapses, suggesting the existence of a completely different postsynaptic complex at inhibitory synapses; this scaffold contains gephyrin, which has not been found at excitatory synapses as a core component (Naisbitt et al., 1997; Feng et al., 1998a,b; Rao et al., 2000) (Welch, Wang, and Feng, unpublished results).

One of the main features of PSD scaffolding proteins is that they all contain multiple protein-protein interacting domains, and each domain can interact with multiple signaling or adaptor proteins (Sheng and Pak, 2000). This has several important implications. First, by recruiting various signaling proteins to the complex, they provide a link from receptor activation to multiple downstream pathways, such as protein phosphorylation (Seabold et al., 2003), transcriptional regulation (Hering and Sheng, 2002), and cytoskeletal interactions (Brenman et al., 1998; Boeckers et al., 1999a; Naisbitt et al., 1999; Passafaro et al., 1999), thus transducing both short-term and long-term effects of synaptic activation. Second, by providing multiple docking sites for signaling and structural proteins, they enable neurons to regulate synaptic structure and function at multiple points for fine tuning. 

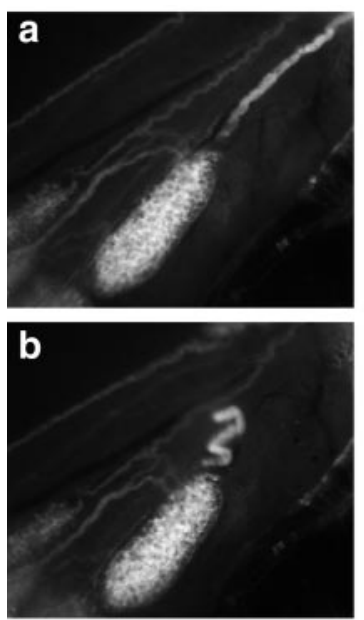

e

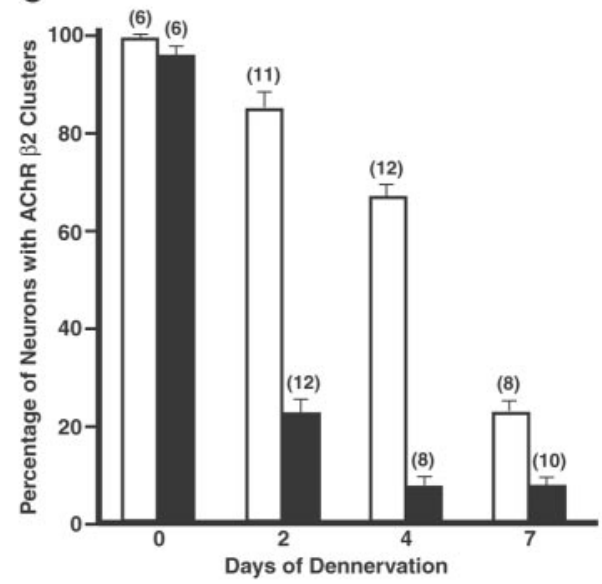

C
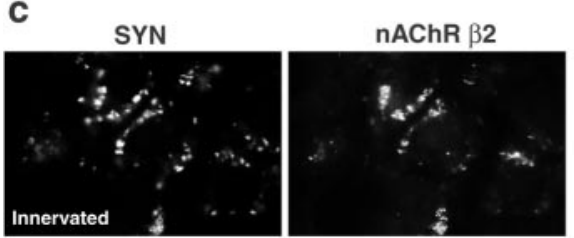

d
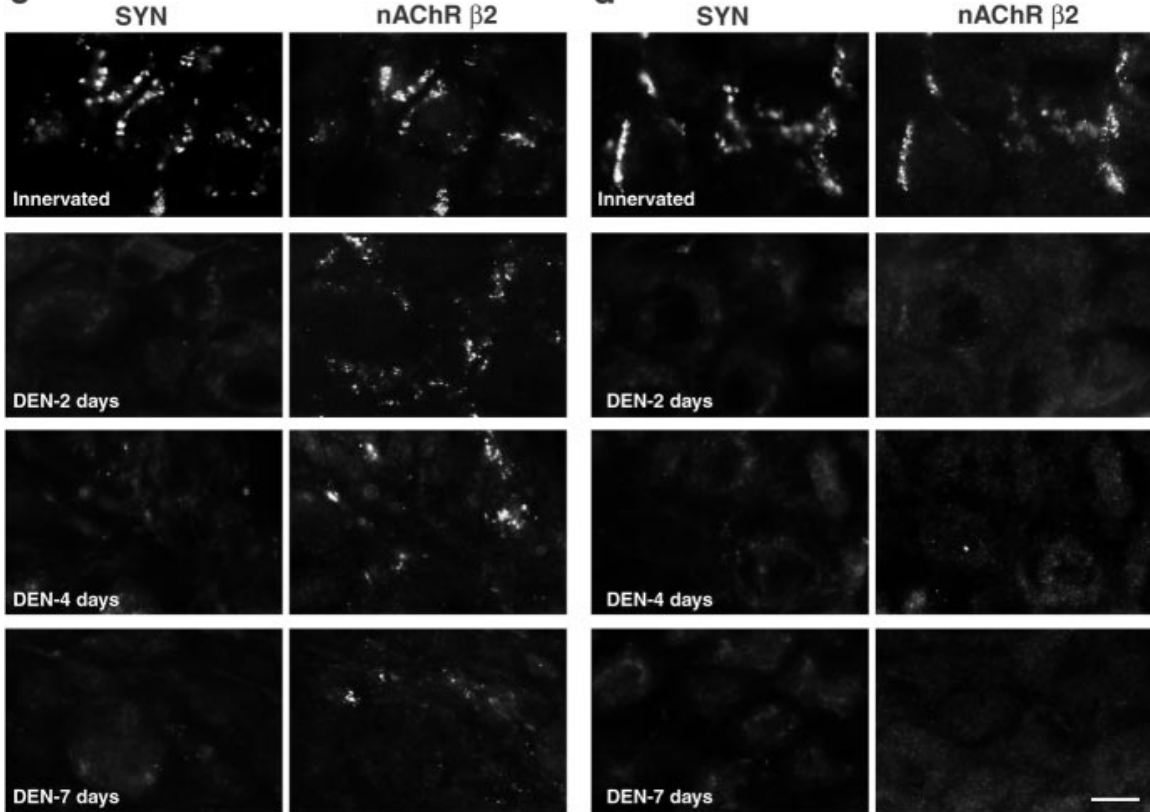

Wildtype SMG
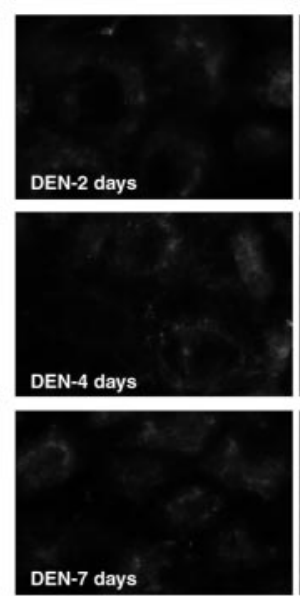

PSD93 mutant SMG

Figure 6. Synaptic clusters of neuronal nAChRs are less stable in denervated SMG of $P S D 93^{-1-}$ mice. $a, b$, To facilitate the denervation procedure of SMG, PSD93 ${ }^{-/-}$mice were mated to Thy1-GFP-J mice, which express GFP in preganglionic axons and terminals but not postganglionic neurons. The pictures show an SMG before $(a)$ and immediately after $(b)$ denervation. $c, d$, Sections of wild-type (c) or PSD93 ${ }^{-/-}$(d) SMG denervated for $0 \mathrm{~d}$ (Innervated), $2 \mathrm{~d}$ (DEN-2 day), $4 \mathrm{~d}$ (DEN-4 day), and $7 \mathrm{~d}$ (DEN-7 day) were double stained with anti-synaptophysin (SYN; left panels) and anti-nAChR $\beta 2$ (right panels). In wild-type SMG, the majority of the $\mathrm{nAChR} \beta 2$ clusters persist $4 \mathrm{~d}$ after denervation (c, right panels). In contrast, most of the $\mathrm{nAChR} \beta 2$ clusters disappear $2 \mathrm{~d}$ after denervation in PSD93 ${ }^{-1-}$ SMG (d, right panels). e, Quantification of percentage of neurons containing $n A C h R$ $\beta 2$ clusters in denervated wild-type (open bars) and $P S D 93^{-/-}$(filled bars) SMG. Numbers on top of the bars indicate the number of denervation experiments performed. Scale bar: $c, d, 5 \mu \mathrm{m}$.

Third, the availability of multiple protein-protein interaction domains enables different types of synapses or the same type of synapse on different types of neurons to assemble unique signaling cascades, thus rendering different synapses with unique functions. For example, Citron, a PSD95-binding protein, is localized at glutamatergic synapses on GABAergic interneurons but not on pyramidal neurons in the hippocampus (Zhang et al., 1999). Previously, little was known about the postsynaptic signaling complex at neuronal cholinergic synapses. The identification of core scaffolding components provides a starting point to elucidate the molecular architecture of this complex.

The N-terminal sequences play important roles in the synap-

tic targeting of MAGUKs. For example, dual palmitoylation through a pair of $\mathrm{N}$-terminal cysteines is essential for targeting PSD95 to the postsynaptic membrane (Topinka and Bredt, 1998; Craven et al., 1999). Recent studies also suggest that a variety of mechanisms are used in the synaptic targeting of MAGUKs through the $\mathrm{N}$-terminal sequences, and alternative splicing may regulate this process. For example, PSD95 $\beta$, an $\mathrm{N}$-terminal splicing variant of PSD95, is not palmitoylated. Instead, its synaptic localization is mediated through the L27 domain unique to this splicing form (Chetkovich et al., 2002). Three N-terminal splicing forms were noted during the initial cloning of PSD93 (Brenman et al., 1996). In this study, we identified three additional N-terminal splicing variants. Among the three new splicing forms identified, one (PSD93 $\delta$ ) contains two pairs of $\mathrm{N}$-terminal cysteines, one (PSD93 $\zeta$ ) has an L27 domain, and the other (PSD93 $\epsilon$ ) contains neither motif. It has been shown that the first 30 amino acids in PSD93 $\alpha$ are required for synaptic targeting but palmitoylation is not (Firestein et al., 2000), suggesting a novel mechanism for targeting PSD93 $\alpha$ to the postsynaptic membrane. Interestingly, the $\mathrm{N}$-terminal sequence of PSD93 $\delta$, the predominant splicing form at neuronal cholinergic synapses, is distinct from that of PSD93 $\alpha$ and bears no homology to any known sequences in the database, suggesting that yet another type of mechanism may be involved in the synaptic targeting of PSD93. Because all three new isoforms are also expressed in the brain, we suggest that different types of neurons in the brain may regulate synaptic function through the expression of different splicing forms of PSD93.

It is not clear how nAChRs interact with PSD93 in the postsynaptic complex. MAGUKs typically bind to the last three amino acids (S/T X V) of the C termini of neurotransmitter receptors through PDZ domain interactions. Interestingly, both the $\mathrm{N}$ termini and $\mathrm{C}$ termini of all $\mathrm{nAChRs}$ are extracellular (Lindstrom, 1996), suggesting a different mode of interaction between PSD93 and nAChRs. Interaction of MAGUKs with neurotransmitter receptors through an intermediate protein is well studied in the case of PSD95 and AMPA receptors. Binding of PSD95 through its PDZ domains to the AMPA receptor-associated protein Stargazin regulates the synaptic targeting of AMPA receptors (Chen et al., 2000; Schnell et al., 2002), and a similar mechanism may be used by cholinergic neurons. Interestingly, two short forms of PSD93, which lack the entire latter half of the protein, including the $\mathrm{SH} 3$ and the GK domain, were recently identified from chick ciliary ganglion neurons (Conroy et al., 2003). It was shown that one of the short forms (chick PSD93a) interacts with neuronal nAChRs 
when cotransfected into HEK293 cells, and both the N-terminal sequences and the PDZ domains are important for this interaction (Conroy et al., 2003). Neither of the two short forms has been reported in mammals, and we did not detect similar short forms from our screening of mouse SCG libraries. It is therefore not clear whether the mammalian PSD93 isoforms also directly interact with nAChRs. Nevertheless, the large cytoplasmic loop of the $\alpha 3$ subunit of neuronal nAChRs has been shown to mediate synaptic targeting and/or anchoring the receptor in chick ciliary ganglia (Williams et al., 1998). Because this loop is also the main cytoplasmic region of the receptor, it is likely that the interaction of PSD93 with nAChRs, direct or indirect, involves this loop.

Despite intensive study, the function of MAGUKs at vertebrate synapses remains poorly understood (McGee and Bredt, 2003). Our data provide the first evidence that PSD93 plays a role in the stabilization of receptor clusters at neuronal cholinergic synapses. Although the mechanism is unclear, PSD93 may act by linking receptor clusters to the cytoskeleton via interactions with GKAP/SAPAP and Shank/ProSAP, which interact with actin through Cortactin. Alternatively, PSD93 may regulate the trafficking and targeting of nAChRs to the postsynaptic membrane. It is well documented that the density of neurotransmitter receptors in the PSD is dynamically regulated by neuronal activity (Carroll and Zukin, 2002; Malinow and Malenka, 2002; Wenthold et al., 2003), and regulation through ubiquitinproteasome degradation (Ehlers, 2003) and PSD95-mediated trafficking and targeting both play important roles in this process (Chen et al., 2000; Shi et al., 2001; Schnell et al., 2002). Thus, the accelerated disassembly of synaptic nAChR clusters in PSD93 null mice may reflect impaired trafficking and/or targeting of $\mathrm{nAChRs}$ to the postsynaptic membrane. Distinguishing these mechanisms in future studies will likely help us to further understand the function of MAGUKs at cholinergic as well as glutamatergic synapses.

\section{References}

Aoki C, Miko I, Oviedo H, Mikeladze-Dvali T, Alexandre L, Sweeney N, Bredt DS (2001) Electron microscopic immunocytochemical detection of PSD-95, PSD-93, SAP-102, and SAP-97 at postsynaptic, presynaptic, and nonsynaptic sites of adult and neonatal rat visual cortex. Synapse 40:239-257.

Boeckers TM, Kreutz MR, Winter C, Zuschratter W, Smalla KH, Sanmarti-Vila L, Wex H, Langnaese K, Bockmann J, Garner CC, Gundelfinger ED (1999a) Proline-rich synapse-associated protein-1/cortactin binding protein 1 (Pro$\mathrm{SAP} 1 / \mathrm{CortBP} 1$ ) is a PDZ-domain protein highly enriched in the postsynaptic density. J Neurosci 19:6506-6518.

Boeckers TM, Winter C, Smalla KH, Kreutz MR, Bockmann J, Seidenbecher C, Garner CC, Gundelfinger ED (1999b) Proline-rich synapseassociated proteins ProSAP1 and ProSAP2 interact with synaptic proteins of

the

SAPAP/GKAP family. Biochem Biophys Res Commun 264:247-252.

Brenman JE, Christopherson KS, Craven SE, McGee AW, Bredt DS (1996)
Cloning and characterization of postsynaptic density 93, a nitric oxide synthase interacting protein. J Neurosci 16:7407-7415.

Brenman JE, Topinka JR, Cooper EC, McGee AW, Rosen J, Milroy T, Ralston HJ, Bredt DS (1998) Loclization of postsynaptic density-93 to dendritic microtubules and interaction with microtubule-associated protein $1 \mathrm{~A}$. J Neurosci 18:8805-8813.

Buckley K, Kelly RB (1985) Identification of a transmembrane glycoprotein specific for secretory vesicles of neural and endocrine cells. J Cell Biol 100:1284-1294.

Carlin RK, Grab DJ, Cohen RS, Siekevitz P (1980) Isolation and characterization of postsynaptic densities from various brain regions: enrichment of different types of postsynaptic densities. J Cell Biol 86:831-845.

Carroll RC, Zukin RS (2002) NMDA-receptor trafficking and targeting: implications for synaptic transmission and plasticity. Trends Neurosci 25:571-577.

Chen HJ, Rojas-Soto M, Oguni A, Kennedy MB (1998) A synaptic RasGTPase activating protein (p135 SynGAP) inhibited by CaM kinase II. Neuron 20:895-904.

Chen L, Chetkovich DM, Petralia RS, Sweeney NT, Kawasaki Y, Wenthold RJ, Bredt DS, Nicoll RA (2000) Stargazin regulates synaptic targeting of AMPA receptors by two distinct mechanisms. Nature 408:936-943.

Chetkovich DM, Bunn RC, Kuo SH, Kawasaki Y, Kohwi M, Bredt DS (2002) Postsynaptic targeting of alternative postsynaptic density- 95 isoforms by distinct mechanisms. J Neurosci 22:6415-6425.

Cho KO, Hunt CA, Kennedy MB (1992) The rat brain postsynaptic density fraction contains a homolog of the Drosophila discs-large tumor suppressor protein. Neuron 9:929-942.

Conroy WG, Liu Z, Nai Q, Coggan JS, Berg DK (2003) PDZ-containing proteins provide a functional postsynaptic scaffold for nicotinic receptors in neurons. Neuron 38:759-771.

Craven SE, El-Husseini AE, Bredt DS (1999) Synaptic targeting of the postsynaptic density protein PSD-95 mediated by lipid and protein motifs. Neuron 22:497-509.

Dani JA, Heinemann S (1996) Molecular and cellular aspects of nicotine abuse. Neuron 16:905-908. 
Du Y, Weed SA, Xiong WC, Marshall TD, Parsons JT (1998) Identification of a novel cortactin SH3 domain-binding protein and its localization to growth cones of cultured neurons. Mol Cell Biol 18:5838-5851.

Ehlers MD (2003) Activity level controls postsynaptic composition and signaling via the ubiquitin-proteasome system. Nat Neurosci 6:231-242.

Feng G, Steinbach JH, Sanes JR (1998a) Rapsyn clusters neuronal acetylcholine receptors but is inessential for formation of an interneuronal cholinergic synapse. J Neurosci 18:4166-4176.

Feng G, Tintrup H, Kirsch J, Nichol MC, Kuhse J, Betz H, Sanes JR (1998b) Dual requirement for gephyrin in glycine receptor clustering and molybdoenzyme activity. Science 282:1321-1324.

Feng G, Mellor RH, Bernstein M, Keller-Peck C, Nguyen QT, Wallace M, Nerbonne JM, Lichtman JW, Sanes JR (2000) Imaging neuronal subsets in transgenic mice expressing multiple spectral variants of GFP. Neuron 28:41-51.

Firestein BL, Craven SE, Bredt DS (2000) Postsynaptic targeting of MAGUKs mediated by distinct N-terminal domains. NeuroReport 11:3479-3484.

Freeman RS, Estus S, Johnson Jr EM (1994) Analysis of cell cycle-related gene expression in postmitotic neurons: selective induction of Cyclin D1 during programmed cell death. Neuron 12:343-355.

Gan WB, Kwon E, Feng G, Sanes J, Lichtman J (2003) Age-dependent decline in synaptic dynamism in an adult mouse parasympathetic ganglion. Nat Neurosci 6:1-5.

Garner CC, Nash J, Huganir RL (2000) PDZ domains in synapse assembly and signalling. Trends Cell Biol 10:274-280.

Gruber AD, Levine RA (1997) In situ assessment of mRNA accessibility in heterogeneous tissue samples using elongation factor-1 alpha (EF-1 alpha). Histochem Cell Biol 107:411-416.

Hering H, Sheng M (2002) Direct interaction of Frizzled-1, -2, -4 and -7 with PDZ domains of PSD-95. FEBS Lett 521:185-189.

Husi H, Ward MA, Choudhary JS, Blackstock WP, Grant SG (2000) Proteomic analysis of NMDA receptor-adhesion protein signaling complexes. Nat Neurosci 3:661-669.

Kawa K, Roper S (1984) On the two subdivisions and intrinsic synaptic connexions in the submandibular ganglion of the rat. J Physiol (Lond) 346:301-320.

Kennedy MB (2000) Signal-processing machines at the postsynaptic density. Science 290:750-754.

Kim E, Cho KO, Rothschild A, Sheng M (1996) Heteromultimerization and NMDA receptor-clustering activity of Chapsyn-110, a member of the PSD-95 family of proteins. Neuron 17:103-113.

Kim E, Naisbitt S, Hsueh YP, Rao A, Rothschild A, Craig AM, Sheng M (1997) GKAP, a novel synaptic protein that interacts with the guanylate kinase-like domain of the PSD-95/SAP90 family of channel clustering molecules. J Cell Biol 136:669-678.

Kim JH, Liao D, Lau LF, Huganir RL (1998) SynGAP: a synaptic RasGAP that associates with the PSD-95/SAP90 protein family. Neuron 20:683-691.

Kistner U, Wenzel BM, Veh RW, Cases-Langhoff C, Garner AM, Appeltauer U, Voss B, Gundelfinger ED, Garner CC (1993) SAP90, a rat presynaptic protein related to the product of the Drosophila tumor suppressor gene dlg-A. J Biol Chem 268:4580-4583.

Lau LF, Mammen A, Ehlers MD, Kindler S, Chung WJ, Garner CC, Huganir RL (1996) Interaction of the $N$-methyl-D-aspartate receptor complex with a novel synapse-associated protein, SAP102. J Biol Chem 271:21622-21628.

Lena C, Changeux JP (1997) Pathological mutations of nicotinic receptors and nicotine-based therapies for brain disorders. Curr Opin Neurobiol 7:674-682.

Lichtman JW (1977) The reorganization of synaptic connexions in the rat submandibular ganglion during post-natal development. J Physiol (Lond) 273:155-177.

Lindstrom J (1996) Neuronal nicotinic acetylcholine receptors. Ion Channels 4:377-450.

Lindstrom J (1997) Nicotinic acetylcholine receptors in health and disease. Mol Neurobiol 15:193-222.

Lue RA, Marfatia SM, Branton D, Chishti AH (1994) Cloning and characterization of hdlg: the human homologue of the Drosophila discs large tumor suppressor binds to protein 4.1. Proc Natl Acad Sci USA 91:9818-9822.

Malinow R, Malenka RC (2002) AMPA receptor trafficking and synaptic plasticity. Annu Rev Neurosci 25:103-126.

McGee AW, Bredt DS (2003) Assembly and plasticity of the glutamatergic postsynaptic specialization. Curr Opin Neurobiol 13:111-118.

McGee AW, Topinka JR, Hashimoto K, Petralia RS, Kakizawa S, Kauer F, Aguilera-Moreno A, Wenthold RJ, Kano M, Bredt DS (2001) PSD-93 knock-out mice reveal that neuronal MAGUKs are not required for development or function of parallel fiber synapses in cerebellum. J Neurosci 21:3085-3091.

Muller BM, Kistner U, Veh RW, Cases-Langhoff C, Becker B, Gundelfinger ED, Garner CC (1995) Molecular characterization and spatial distribution of SAP97, a novel presynaptic protein homologous to SAP90 and the Drosophila discs-large tumor suppressor protein. J Neurosci 15:2354-2366.

Muller BM, Kistner U, Kindler S, Chung WJ, Kuhlendahl S, Fenster SD, Lau LF, Veh RW, Huganir RL, Gundelfinger ED, Garner CC (1996) SAP102, a novel postsynaptic protein that interacts with NMDA receptor complexes in vivo. Neuron 17:255-265.

Naisbitt S, Kim E, Weinberg RJ, Rao A, Yang FC, Craig AM, Sheng M (1997) Characterization of guanylate kinase-associated protein, a postsynaptic density protein at excitatory synapses that interacts directly with postsynaptic density-95/synapse-associated protein 90 . J Neurosci 17:5687-5696.

Naisbitt S, Kim E, Tu JC, Xiao B, Sala C, Valtschanoff J, Weinberg RJ, Worley PF, Sheng M (1999) Shank, a novel family of postsynaptic density proteins that binds to the NMDA receptor/PSD-95/GKAP complex and cortactin. Neuron 23:569-582.

Passafaro M, Sala C, Niethammer M, Sheng M (1999) Microtubule binding by CRIPT and its potential role in the synaptic clustering of PSD-95. Nat Neurosci 2:1063-1069.

Perry E, Walker M, Grace J, Perry R (1999) Acetylcholine in mind: a neurotransmitter correlate of consciousness? Trends Neurosci 22:273-280.

Purves D, Hadley RD (1985) Changes in the dendritic branching of adult mammalian neurones revealed by repeated imaging in situ. Nature 315:404-406.

Purves D, Lichtman JW (1985) Geometrical differences among homologous neurons in mammals. Science 228:298-302.

Rafael JA, Hutchinson TL, Lumeng CN, Marfatia SM, Chishti AH, Chamberlain JS (1998) Localization of Dlg at the mammalian neuromuscular junction. NeuroReport 9:2121-2125.

Rao A, Cha EM, Craig AM (2000) Mismatched appositions of presynaptic and postsynaptic components in isolated hippocampal neurons. J Neurosci 20:8344-8353.

Role LW, Berg DK (1996) Nicotinic receptors in the development and modulation of CNS synapses. Neuron 16:1077-1085.

Rumbaugh G, Sia GM, Garner CC, Huganir RL (2003) Synapse-associated protein-97 isoform-specific regulation of surface AMPA receptors and synaptic function in cultured neurons. J Neurosci 23:4567-4576.

Satoh K, Yanai H, Senda T, Kohu K, Nakamura T, Okumura N, Matsumine A, Kobayashi S, Toyoshima K, Akiyama T (1997) DAP-1, a novel protein that interacts with the guanylate kinase-like domains of hDLG and PSD95. Genes Cells 2:415-424.

Schnell E, Sizemore M, Karimzadegan S, Chen L, Bredt DS, Nicoll RA (2002) Direct interactions between PSD-95 and stargazin control synaptic AMPA receptor number. Proc Natl Acad Sci USA 99:13902-13907.

Seabold GK, Burette A, Lim IA, Weinberg RJ, Hell JW (2003) Interaction of the tyrosine kinase Pyk2 with the $N$-methyl-D-aspartate receptor complex via the Src homology 3 domains of PSD-95 and SAP102. J Biol Chem 278:15040-15048.

Sheng M, Kim E (2000) The Shank family of scaffold proteins. J Cell Sci 113:1851-1856.

Sheng M, Pak DT (2000) Ligand-gated ion channel interactions with cytoskeletal and signaling proteins. Annu Rev Physiol 62:755-778.

Sheng M, Sala C (2001) PDZ domains and the organization of supramolecular complexes. Annu Rev Neurosci 24:1-29.

Shi S, Hayashi Y, Esteban JA, Malinow R (2001) Subunit-specific rules governing AMPA receptor trafficking to synapses in hippocampal pyramidal neurons. Cell 105:331-343. 
Snider WD (1987) The dendritic complexity and innervation of submandibular neurons in five species of mammals. J Neurosci 7:1760-1768.

Takeuchi M, Hata Y, Hirao K, Toyoda A, Irie M, Takai Y (1997) SAPAPs. a family of PSD-95/SAP90-associated proteins localized at postsynaptic density. J Biol Chem 272:11943-11951.

Topinka JR, Bredt DS (1998) N-terminal palmitoylation of PSD-95 regulates association with cell membranes and interaction with $\mathrm{K}^{+}$channel Kv1.4. Neuron 20:125-134

Walikonis RS, Jensen ON, Mann M, Provance Jr DW, Mercer JA, Kennedy MB (2000) Identification of proteins in the postsynaptic density fraction by mass spectrometry. J Neurosci 20:4069-4080.

Wenthold RJ, Prybylowski K, Standley S, Sans N, Petralia RS (2003) Trafficking of NMDA receptors. Annu Rev Pharmacol Toxicol 43:335-358.
Whiting PJ, Schoepfer R, Swanson LW, Simmons DM, Lindstrom JM (1987) Functional acetylcholine receptor in PC12 cells reacts with a monoclonal antibody to brain nicotinic receptors. Nature 327:515-518.

Williams BM, Temburni MK, Levey MS, Bertrand S, Bertrand D, Jacob MH (1998) The long internal loop of the alpha 3 subunit targets nAChRs to subdomains within individual synapses on neurons in vivo. Nat Neurosci $1: 557-562$.

Yamauchi T (2002) Molecular constituents and phosphorylationdependent regulation of the post-synaptic density. Mass Spectrom Rev 21:266-286.

Zhang W, Vazquez L, Apperson M, Kennedy MB (1999) Citron binds to PSD-95 at glutamatergic synapses on inhibitory neurons in the hippocampus. J Neurosci 19:96-108. 